\title{
Twenty New Records of Bees (Hymenoptera, Apoidea) for Sardinia (Italy)
}

\author{
Vittorio Nobile $^{1}$, Roberto Catania ${ }^{2}\left(\mathbb{D}\right.$, Pietro Niolu ${ }^{3}$, Michelina Pusceddu ${ }^{4}$, Alberto Satta ${ }^{4}\left(\mathbb{D}\right.$, Ignazio Floris ${ }^{4, *} * \mathbb{D}$, \\ Simone Flaminio ${ }^{5}\left(\mathbb{D}\right.$, Salvatore Bella ${ }^{2, *}$ and Marino Quaranta ${ }^{5}$ \\ 1 Indipendent Researcher, 97100 Ragusa, Italy; nobilevittorio@tin.it \\ 2 Centro di Ricerca Olivicoltura, Frutticoltura e Agrumicoltura, (CREA) Consiglio per la Ricerca in Agricoltura \\ e l'analisi dell'Economia Agraria, Corso Savoia 190, 95024 Acireale, Italy; robertocatania1995@libero.it \\ 3 Indipendent Researcher, 07041 Alghero, Italy; pietroniolu@libero.it \\ 4 Department of Agricultural Sciences, University of Sassari, Viale Italia 39, 07100 Sassari, Italy; \\ mpusceddu@uniss.it (M.P.); albsatta@uniss.it (A.S.) \\ 5 Centro di Ricerca Agricoltura e Ambiente, (CREA) Consiglio per la Ricerca in Agricoltura e l'analisi \\ dell'Economia Agraria-via di Corticella 133, I-40128 Bologna, Italy; simone.flaminio@crea.gov.it (S.F.); \\ marino.quaranta@crea.gov.it (M.Q.) \\ * Correspondence: ifloris@uniss.it (I.F.); salvatore.bella@crea.gov.it (S.B.); Tel.: +39-079-229360 (I.F.)
}

check for updates

Citation: Nobile, V.; Catania, R.; Niolu, P.; Pusceddu, M.; Satta, A.; Floris, I.; Flaminio, S.; Bella, S.; Quaranta, M. Twenty New Records of Bees (Hymenoptera, Apoidea) for Sardinia (Italy). Insects 2021, 12, 627. https://doi.org/10.3390/ insects12070627

Academic Editors: Claus Rasmussen and Andrew Polaszek

Received: 2 May 2021

Accepted: 7 July 2021

Published: 10 July 2021

Publisher's Note: MDPI stays neutral with regard to jurisdictional claims in published maps and institutional affiliations.

Copyright: (c) 2021 by the authors. Licensee MDPI, Basel, Switzerland. This article is an open access article distributed under the terms and conditions of the Creative Commons Attribution (CC BY) license (https:// creativecommons.org/licenses/by/ $4.0 /)$.
Simple Summary: Recently, several studies have highlighted the global decline of pollinators. This has increased concern for the long-term sustainability of plant biodiversity, food production, human nutrition, and human well-being. In Europe, approximately $40 \%$ of bee species are threatened in some countries. The Mediterranean Basin is one of the richest areas of diversity of wild bees. Sardinia, the second largest island in the basin, has a flora and fauna with many endemic taxa. Until recently, a number of 316 species of bees was reported on the island. However, the identification of the bee fauna of Sardinia still remains incomplete compared to other islands of the Mediterranean Basin, such as Sicily, Malta, Cyprus, and the Balearic Islands. It is very important to know and protect the potentially rich bee biodiversity of Sardinia, considering that the different factors that now threaten wild pollinators in Europe could lead to its impairment. This paper reports 20 new records of bee species from Sardinia based on observations made in different coastal and mountain ecosystems of the island. These findings contribute to the knowledge of the systematics and distribution of the Sardinian bee fauna.

Abstract: In Sardinia, the second largest Mediterranean island, 316 species of bees are known. Here, for the first time, the following 20 taxa are reported: Colletes cunicularius (Linnaeus, 1761), and C. eous Morice, 1904 (Colletidae); Andrena humilis Imhoff, 1832, A. granulosa Pérez, 1902, A. cineraria (Linnaeus, 1758), A. pallitarsis Pérez, 1903, A. rugulosa Stöckhert, 1935, A. savignyi Spinola, 1838, and A. tenuistriata Pérez, 1895 (Andrenidae); Sphecodes reticulatus Thomson, 1870 (Halictidae); Lithurgus tibialis Morawitz, 1875, Chelostoma emarginatum (Nylander, 1856), Dioxys cinctus (Jurine, 1807), Coelioxys caudatus Spinola, 1838, C. obtusus Pérez, 1884, and Megachile ericetorum (Lepeletier, 1841) (Megachilidae); and Nomada melathoracica Imhoff, 1834, N. pulchra Arnold, 1888, Eucera proxima Morawitz, 1875 and Tetralonia malvae (Rossi, 1790) (Apidae). N. pulchra is reported for the first time in Italy.

Keywords: Colletidae; Andrenidae; Halictidae; Megachilidae; Apidae; Mediterranean; pollinators; wild bees; Sardinia; biogeography; distribution; fauna

\section{Introduction}

One of the major hotspots for plant and animal diversity in Europe and the world is the Mediterranean Basin, which is characterized by a high incidence of endemic entities (species or subspecies) [1] and is one of the richest areas of diversity of wild bees (Hymenoptera, Apoidea) [2-4]. 
Recently, several reviews have highlighted the global decline of insects $[5,6]$ including pollinators [7-9]. This has increased concern for the long-term sustainability of plant biodiversity, food production, human nutrition, and human well-being. The International Union for Conservation of Nature and Natural Resources (IUCN) European Red List for bees shows that $37 \%$ of bee species suffer from declining populations. Approximately $9 \%$ of all bees and $26 \%$ of bumblebees are classified as threatened, whereas $57 \%$ of bee species could not be assessed because of insufficient data [3]. In some cases, national Red Lists in Europe indicate that approximately up to $40 \%$ of bee species are threatened [9].

Probably the most important role of bees for humans is the pollination of wild plants with respect to the pollination of crops. Because most plant species are pollinated by insects, especially bees, the conservation of many habitats depends on their preservation. This is particularly important for wild species, many of which are pollen specialists on certain kinds of flowers, often with a strong preference for a given species. Hence, it is important to investigate wild bees in a certain region, in order to prevent their reduction due to the destruction of natural habitats or food competition with honey bees, especially when hive density is high.

In the Mediterranean Basin, Sardinia is the second largest island after Sicily, with a surface of $24,089 \mathrm{~km}^{2}$. Sardinia shows unique flora and fauna characteristics related to paleogeographic connections with other Mediterranean cross-border regions [10]. It is located between $38^{\circ} 51^{\prime} 52^{\prime \prime}$ and $41^{\circ} 15^{\prime} 42^{\prime \prime} \mathrm{N}$ latitude and between $8^{\circ} 8^{\prime}$ and $9^{\circ} 50^{\prime} \mathrm{E}$ longitude, in the centre of the Western Mediterranean, neighbouring Corsica, about $300 \mathrm{~km}$ from the Ligurian and Provence coasts, $200 \mathrm{~km}$ from the Latium and Tunisian coasts, and $300 \mathrm{~km}$ from Sicily and the Balearic Islands $[10,11]$. The flora and fauna of the island are characterized by the presence of many peculiar species, with some endemic taxa shared with Corsica or other regions, including several species with a very restricted range. For example, the Sardinian Maghrebine, Sardinian Corsican, or Western Mediterranean areas have species such as Anthophora nigrovittata Dours, 1869, Bombus ruderatus sardiniensis Tournier, 1890, B. terrestris sassaricus Tournier, 1890, Epeolus compar Alfken, 1938, Panurgus corsicus Warncke, 1972, and Tetraloniella dentata amseli Alfken, 1938.

Several authors have studied Sardinian bees and other Hymenoptera Aculeata in the last century [12-19], and others have studied the ecological aspects of Apis mellifera L. and other pollinators [20,21]. To date, 316 species of bees are reported in Sardinia [22].

In the last decade, numerous studies on bees have been conducted in different islands of the Mediterranean Basin, such as Sicily [23-28], Malta [29,30], Cyprus [31], and the Balearic Islands [32]. However, the bee fauna of Sardinia still remains incomplete. Apart from some reports, such as Lasioglossum zonulum (Smith, 1848), Sphecodes ferruginatus von Hagens, 1882, and Nomada corcyraea Schmiedecknecht, 1882 [23,24], Osmia spinulosa (Kirby, 1802), and a newly described species, Hoplitis occidentalis Müller, 2012 [33,34], there is a lack of studies on the systematics, distribution, population trends, and ecology of bees in Sardinia [3,35]. It is very important to know and protect the potentially rich bee biodiversity of Sardinia before the different factors that now threaten wild pollinators in Europe could lead to its impairment.

This paper, in which 20 new records of bees are reported for Sardinia, following observations made in different coastal and mountain ecosystems, represents a first attempt to collect more information about bee biodiversity on the island.

\section{Materials and Methods}

Sardinia is included in the Mediterranean biogeographical region and is, therefore, only marginally composed of habitats characteristic of the continental region and, even less so, of the Alpine region. Some habitats of the island are indicated as priority in Natura 2000. Coordinates of the sampling sites as well as the location, mapping, and European classification of the habitats studied are shown in Figures 1 and 2. The sampling sites represent various natural and anthropized habitats located in the main districts (i.e., Cagliari, Nuoro, Oristano, and Sassari) of the island. As an example, two sites representing 
a typical semi-natural area and a semi-intensive farming system of northern Sardinia, the area studied the most in this survey, are shown in Figure 3.
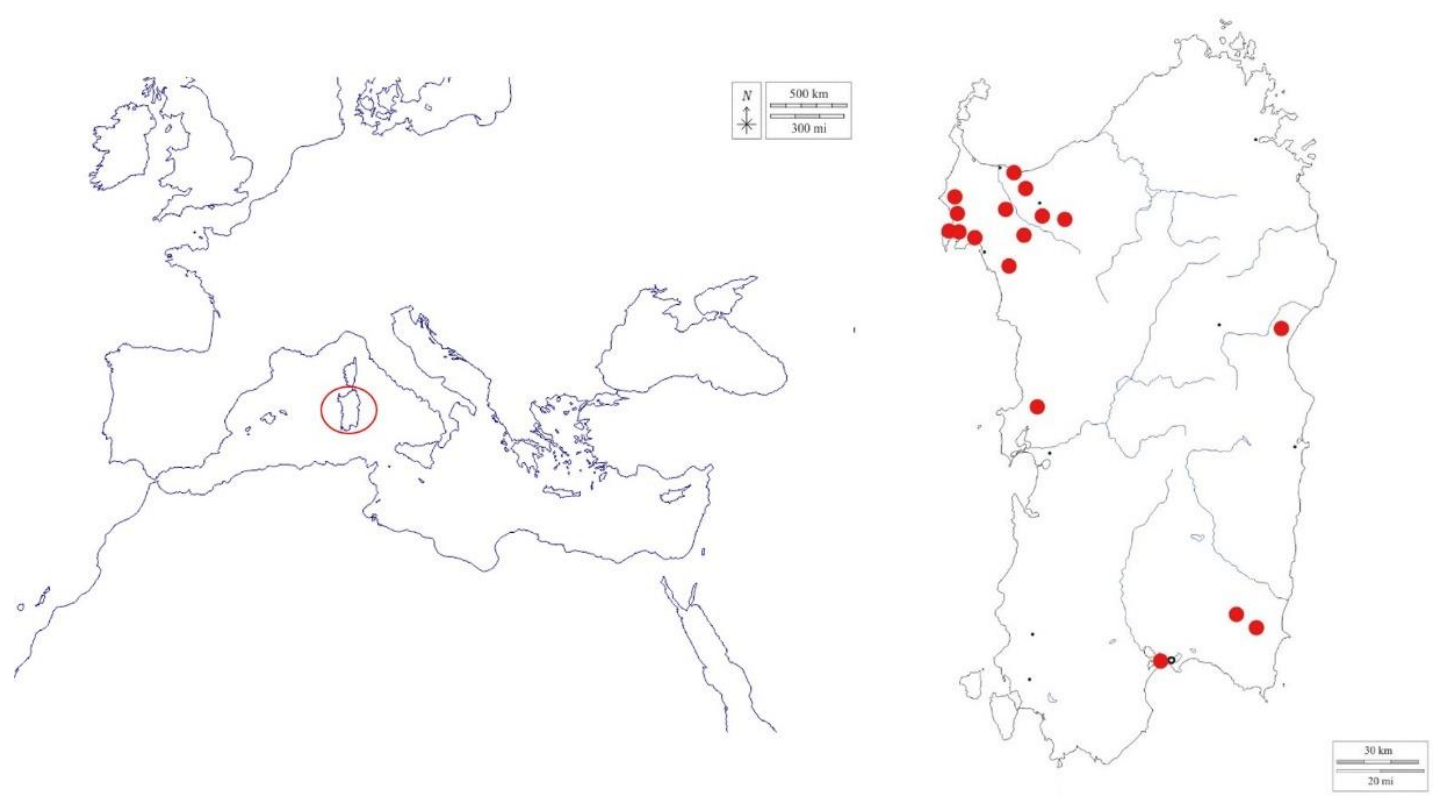

Figure 1. Position of Sardinia in the Mediterranean Basin and sampling sites (red dot) on the island.

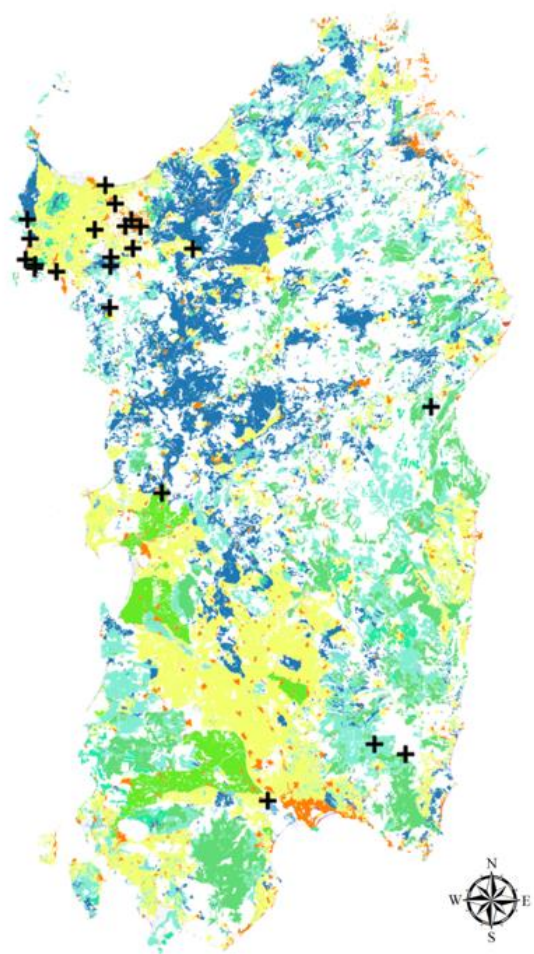

\begin{tabular}{|c|c|c|}
\hline & Habitat types & European classification (EUNIS) \\
\hline L & 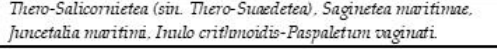 & DH: 1310, 1410; EUNIS A2.55. \\
\hline & Cakliletar maritimae, Salsolo kali-Cakilettum manitimas. & DH: 1210; EUNIS B1.1, B1.21. \\
\hline & 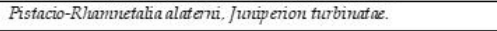 & DH:2250*; EUNIS: B1.63. \\
\hline & Isocto-Nanojounceten Littorelleten, Bidenteten & DH: 3110, 3150; EUNIS. C1.1, C12, C1.3, C1.4. \\
\hline D. & 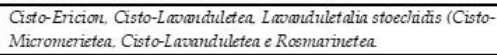 & EUNIS.F5.2. \\
\hline & Rosmurineten Rosmutino-Ericion multifloree, Cisto-Ericion. & EUNIS.F6.1. \\
\hline & Brometalia rubenti-tectori. Stellarietea medine. & EUNIS E1.61. \\
\hline$\square$ & 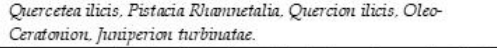 & DH: 2270*, 9540; EUNIS G3.73. \\
\hline$\square$ & 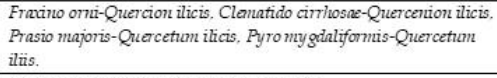 & DH:9340; EUNIS G2.1217. \\
\hline & Pluragnition australis, Glycerio-Sparganion. & EUNIS.D5.1. \\
\hline & Clenopodietalia & EUNIS:11.1,11.2. \\
\hline & Stellavieten. & EUNIS:FB.4. \\
\hline & Artemisieten, Stellarieten & EUNIS.J. \\
\hline & Archeological sites. & EUNIS. 2.51. \\
\hline & Centaurenetallin cymari. & EUNIS:11.3. \\
\hline & Industrial sites. & EUNIS J1.4. \\
\hline
\end{tabular}

Figure 2. Mapping of habitats present in Sardinia [36,37] and sampling sites $(\mathbf{+})$ where the new Apoidea were recorded. 

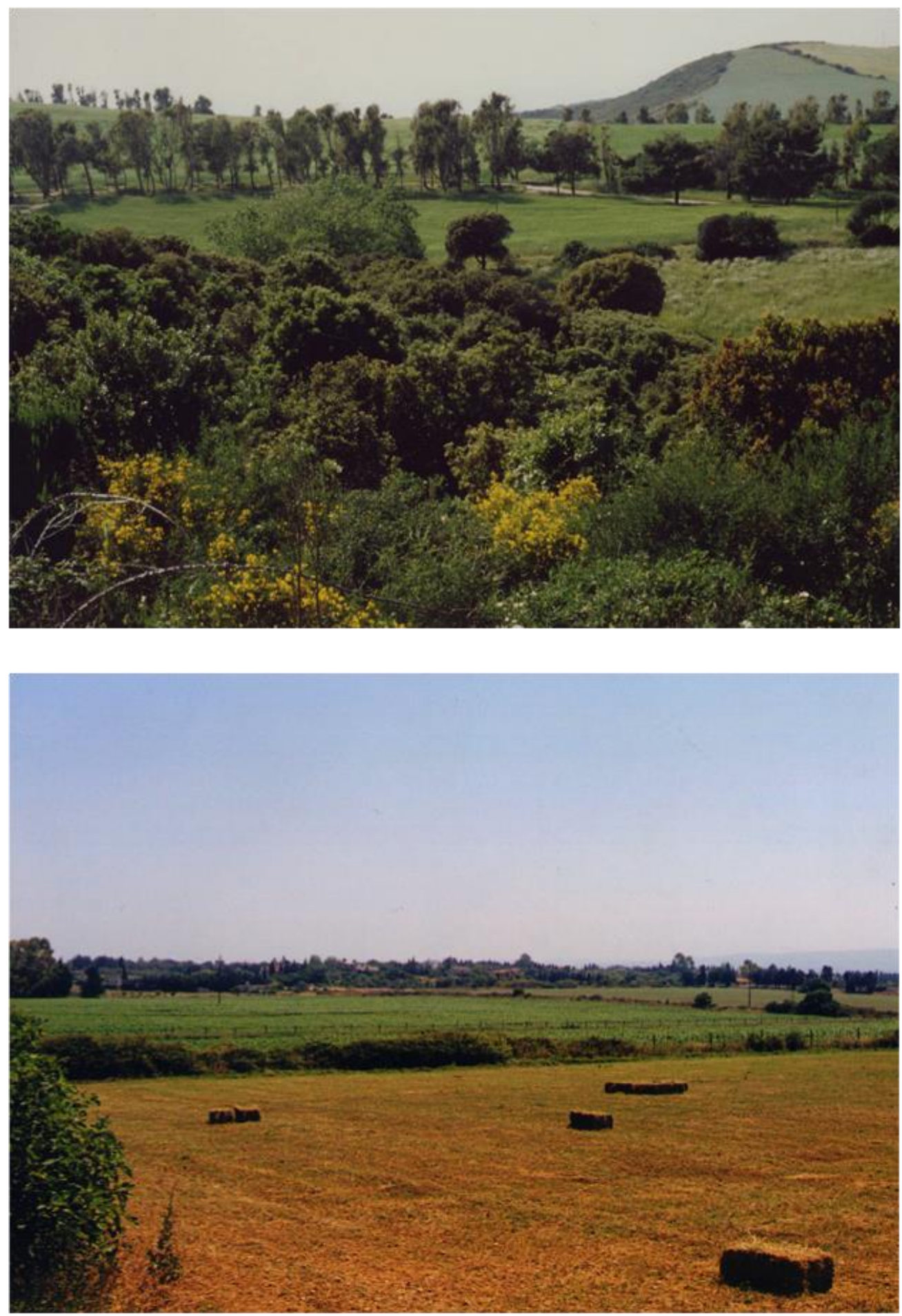

Figure 3. Two study habitats representative of northern Sardinia: a typical semi-natural farming area (Palmadula, SS; above) and a semi-intensive farming system (Ottava, SS; below).

The surveys were conducted during the last decade, specifically by one of the authors (P.N.), in 20 natural sites, characterized by diverse altitudes, from sea level to $516 \mathrm{~m}$ a.s.l., and by different climatic and vegetational conditions, as follows:

\subsection{Sampling Sites}

2.1.1. Cagliari District

Assemini, Rio Flumini Mannu, 39.26, 9.00, 1 m a.s.l. 
Burcei, Nord di Burcei, 39.403250, 9.349528, $430 \mathrm{~m}$ a.s.l.

Burcei, Rio Ollastu, 39.377278, 9.451333, 90 m a.s.l.

\subsubsection{Nuoro District}

Dorgali, Oddoene, 40.257906, 9.541754, 150 m a.s.l.

\subsubsection{Oristano District}

Milis, Santu Simoni, 40.04, 8.65, 70 m a.s.l.

\subsubsection{Sassari District}

Alghero, Calich, Punta Dell'Eru, 40.599763, 8.295892, 3 m a.s.l.

Alghero, Mastr' Antoni, 40.608114, 8.222451, 25 m a.s.l.

Alghero, Cala Viola, 40.629641, 8.192253, 13 m a.s.l.

Alghero, Monte Doglia, 40.616917, 8.224944, 65 m a.s.l.

Olmedo, Strada Statale 291, Janna de Mare, 40.706944, 8.422417, 73 m a.s.l.

Ploaghe, 40.66, 8.75, 360 m a.s.l.

Porto Torres, Spiaggia di Platamona, 40.819722, 8.456758, 1 m a.s.l.

Sassari, Ottava, 40.773194, 8.489889, $70 m$ a.s.l.

Sassari, Palmadula, 40.731750, 8.196861, $200 \mathrm{~m}$ a.s.l.

Sassari, Porto Ferro, 40.683111, 8.206528, 3 m a.s.l.

Sassari, in urbe, $225 \mathrm{~m}$ a.s.l.

Tissi, 40.66, 8.55, $200 m$ a.s.l.

Uri, Cuga, 40.615082, 8.475325, 110 m a.s.l.

Uri, Rio Carrabusu, 40.637330, 8.476420, $100 \mathrm{~m}$ a.s.l.

Villanova Monteleone, Sa Serra, 40.509423, 8.473922, 516 m a.s.l.

\subsection{Acronyms Used in the Text}

AS-Alberto Satta, Sassari, Italy

CA-CREA-AA, Bologna, Italy

CM-Carlo Meloni, Cagliari, Italy

IF-Ignazio Floris, Sassari, Italy

MP_-Michelina Pusceddu, Sassari, Italy

MQ-Marino Quaranta, Bologna, Italy

PN-Pietro Niolu, Alghero, Italy

RC-Roberto Catania, Catania, Italy

SB-Salvatore Bella, Catania, Italy

SF-Simone Flaminio, Bologna, Italy

US-University of Sassari, Italy

VN-Vittorio Nobile, Ragusa, Italy

The distribution, locality and date of collection, number of specimens, visited plants, and collector are given for each bee species. Bees were collected mainly on flowers using a hand net. Sampling was carried out between 9:00 and 17:00. As reported in the text, some specimens came from previous samplings carried out during the second part of the 21th century. All specimens were prepared dry and identified through the observation of sexual structures.

Specimen identification was supported by previous research studies [38-49]. Reference was made to the online checklist of the Western Palearctic Bees by Kuhlmann et al. [49], the Hymenoptera Atlas by Rasmont and Haubruge [50], and the Hymenoptera: Apoidea: Anthophila of Italy by Comba [22]. The classification used in this paper for supra-specific taxa followed Michener [2] and insect nomenclature was according to Polaszek [51]. The studied specimens are preserved in the collections of the authors and in the entomological collections of CA and US. 


\section{Results}

Overall, the following 20 species of Apoidea reported here belong to five different families and 11 genera (Table 1, Figure 4). Table 2 summarizes, comparatively, the data of the 20 species recorded in Italy and in other Mediterranean countries [52] before our study.

Table 1. List of recorded species of Apoidea that were new for Sardinia (Sa) and, in one case, for Italy (IT).

\begin{tabular}{|c|c|c|c|c|}
\hline $\mathbf{N}^{\circ}$ & Taxon & $\mathbf{N}^{\circ}$ of Specimens & Botanical Choice & New for Sa/IT \\
\hline \multicolumn{5}{|c|}{ Fam. Colletidae } \\
\hline 1 & $\begin{array}{c}\text { Colletes cunicularius (Linnaeus, } \\
\text { 1761) }\end{array}$ & 10 & & Sa \\
\hline 2 & Colletes eous Morice, 1904 & 1 & & Sa \\
\hline \multicolumn{5}{|c|}{ Fam. Andrenidae } \\
\hline 3 & $\begin{array}{c}\text { Andrena (Chlorandrena) humilis } \\
\text { Imhoff, } 1832\end{array}$ & 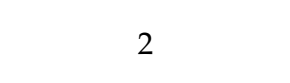 & & Sa \\
\hline 4 & $\begin{array}{c}\text { Andrena (Euandrena) granulosa } \\
\text { Pérez, } 1902\end{array}$ & 1 & & Sa \\
\hline 5 & $\begin{array}{c}\text { Andrena (Melandrena) cineraria } \\
\text { (Linnaeus, } 1758)\end{array}$ & 1 & & Sa \\
\hline 6 & $\begin{array}{l}\text { Andrena (Micrandrena) } \\
\text { tenuistriata Pérez, } 1895\end{array}$ & 1 & Asteraceae & Sa \\
\hline 7 & $\begin{array}{c}\text { Andrena (Micrandrena) rugulosa } \\
\text { Stöckhert, } 1935\end{array}$ & 1 & & Sa \\
\hline 8 & $\begin{array}{c}\text { Andrena (Notandrena) pallitarsis } \\
\text { Pérez, } 1903\end{array}$ & 1 & Apiaceae & Sa \\
\hline 9 & $\begin{array}{c}\text { Andrena (Suandrena) savignyi } \\
\text { Spinola, } 1838\end{array}$ & 4 & & Sa \\
\hline \multicolumn{5}{|c|}{ Fam. Halictidae } \\
\hline 10 & $\begin{array}{l}\text { Sphecodes reticulatus Thomson, } \\
1870\end{array}$ & 1 & & Sa \\
\hline \multicolumn{5}{|c|}{ Fam. Megachilidae } \\
\hline 11 & $\begin{array}{l}\text { Lithurgus (Lithurgus) tibialis } \\
\text { Morawitz, } 1875\end{array}$ & 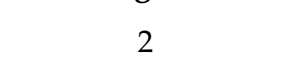 & Euphorbiaceae & Sa \\
\hline 12 & $\begin{array}{c}\text { Chelostoma (Chelostoma) } \\
\text { emarginatum (Nylander, 1856) }\end{array}$ & 1 & Ranunculaceae & Sa \\
\hline 13 & Dioxys cinctus (Jurine, 1807) & 1 & & Sa \\
\hline 14 & $\begin{array}{c}\text { Coelioxys (Allocoelioxys) caudatus } \\
\text { Spinola, } 1838\end{array}$ & 1 & & Sa \\
\hline 15 & $\begin{array}{c}\text { Coelioxys (Allocoelioxys) obtusus } \\
\text { Pérez, } 1884\end{array}$ & 4 & Apiaceae & Sa \\
\hline 16 & $\begin{array}{l}\text { Megachile (Pseudomegachile) } \\
\text { ericetorum (Lepeletier, 1841) }\end{array}$ & 2 & & Sa \\
\hline \multicolumn{5}{|c|}{ Fam. Apidae } \\
\hline 17 & $\begin{array}{c}\text { Nomada melathoracica Imhoff, } \\
1834\end{array}$ & 1 & & Sa \\
\hline 18 & Nomada pulchra Arnold, 1888 & 1 & & IT, Sa \\
\hline 19 & $\begin{array}{c}\text { Eucera (Eucera) proxima } \\
\text { Morawitz, } 1875\end{array}$ & 1 & & Sa \\
\hline 20 & $\begin{array}{l}\text { Tetralonia (Tetralonia) malvae } \\
\text { (Rossi, 1790) }\end{array}$ & 2 & Malvaceae & Sa \\
\hline
\end{tabular}



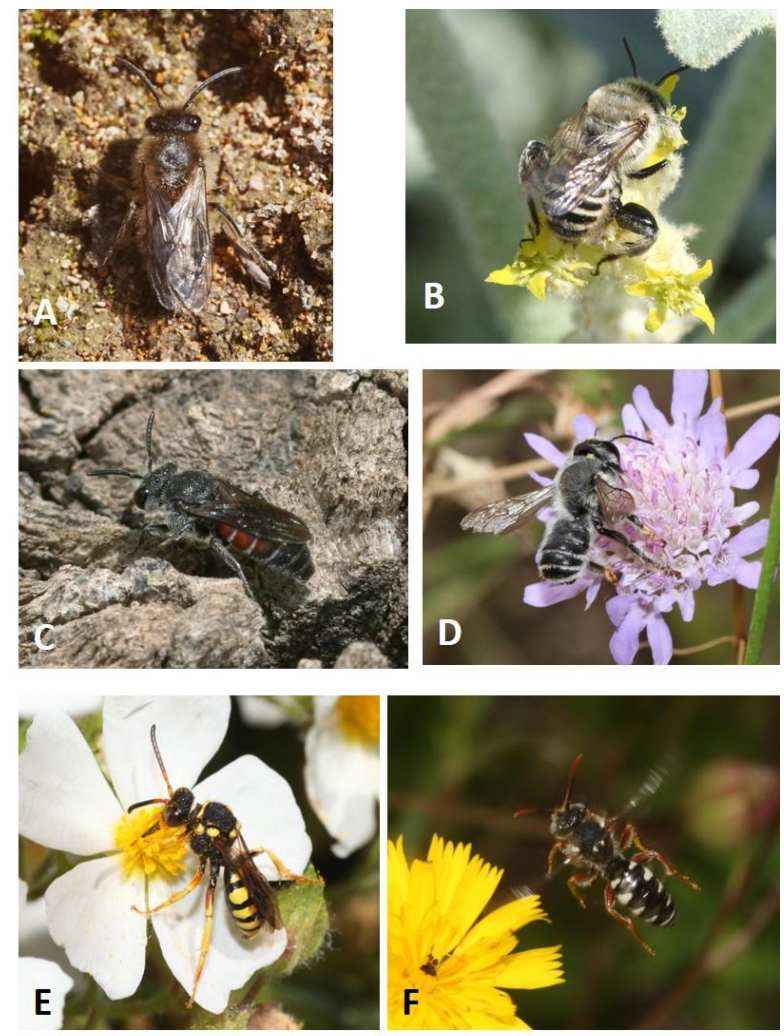

Figure 4. New species of pollinators (Hymenoptera: Apoidea) for Sardinia: (A) Colletes cunicularius; (B) Lithurgus tibialis; (C) Dioxys cinctus; (D) Megachile ericetorum; (E) Nomada melathoracica; and (F) Nomada pulchra (Photos: Pietro Niolu).

Table 2. Comparison between data on the presence $(x)$ of the twenty species of Apoidea in Italy and in Mediterranean coutries.

\begin{tabular}{|c|c|c|c|c|c|c|c|}
\hline Genus & Species & Italy & France & Spain & Morocco & Tunisia & Algeria \\
\hline Andrena & Andrena cineraria & $x$ & $x$ & $x$ & & & \\
\hline Andrena & Andrena granulosa & $x$ & $x$ & $\mathrm{x}$ & $x$ & & \\
\hline Andrena & Andrena humilis & $x$ & $x$ & $x$ & $x$ & $x$ & $x$ \\
\hline Andrena & Andrena pallitarsis & $x$ & $x$ & $x$ & & & \\
\hline Andrena & Andrena rugulosa & $x$ & $x$ & & & & \\
\hline Andrena & Andrena savignyi & $x$ & $x$ & $x$ & $x$ & $x$ & $x$ \\
\hline Andrena & Andrena tenuistriata & $x$ & $x$ & $\mathrm{x}$ & $x$ & $\mathrm{x}$ & $x$ \\
\hline Chelostoma & Chelostoma emarginatum & $x$ & $x$ & $x$ & & $x$ & $x$ \\
\hline Coelioxys & Coelioxys caudata & $x$ & $x$ & $\mathrm{x}$ & $x$ & & $x$ \\
\hline Coelioxys & Coelioxys obtusa & $x$ & $x$ & $\mathrm{x}$ & $x$ & $x$ & $\hat{x}$ \\
\hline Colletes & Colletes cunicularius & $x$ & $x$ & $x$ & & & \\
\hline Colletes & Colletes eous & $x$ & & $x$ & & $x$ & \\
\hline Dioxys & Dioxys cincta & $x$ & $x$ & $x$ & $x$ & $x$ & $x$ \\
\hline Eucera & Eucera proxima & $\mathrm{x}$ & $\mathrm{x}$ & $\mathrm{x}$ & & & \\
\hline Lithurgus & Lithurgus tibialis & $\mathrm{x}$ & & $x$ & & & \\
\hline Megachile & Megachile ericetorum & $\mathrm{x}$ & $x$ & $x$ & $x$ & $x$ & $x$ \\
\hline Nomada & Nomada melathoracica & $\mathrm{x}$ & $x$ & $x$ & & & \\
\hline Nomada & Nomada pulchra & & $\mathrm{x}$ & & & & \\
\hline Sphecodes & Sphecodes reticulatus & $x$ & $x$ & $x$ & & & \\
\hline Tetralonia & Tetralonia malvae & $x$ & $x$ & $x$ & & & \\
\hline
\end{tabular}

\section{Fam. COLLETIDAE}

Gen. Colletes Latreille, 1802

Colletes cunicularius (Linnaeus, 1761) 
Apis cunicularia Linnaeus 1761. Linnaeus 1761: 422.

Examined specimens: Porto Ferro, 3.III.2019, $1 \sigma^{\star}, 19-23 . I I .2021,9 \sigma^{7} \sigma^{7}, \mathrm{PN}$ leg. and det., US and RC coll.

Distribution: widespread in the Palaearctic region [49].

Range in Italy: this species is distributed throughout continental Italy.

Colletes eous Morice, 1904

Colletes eous Morice 1904. Morice 1904: 43-44.

Examined specimens: Cala Viola, 16.VI.2018, $1 \mathrm{o}^{7}$, PN leg. and det., US coll.

Distribution: widespread in Europe (except the colder areas), North Africa (Tunisia), and Southwestern Asia (Armenia, Azerbaijan, Georgia, and Turkey) [49].

Range in Italy: this species is distributed throughout continental Italy.

Fam. ANDRENIDAE

Gen. Andrena Fabricius, 1775

Andrena (Chlorandrena) humilis Imhoff, 1832

Andrena humilis Imhoff 1832. Isis (Oken) Jena: 1201.

Examined specimens: Burcei, Nord di Burcei, 17.IV.2019, $1 \sigma^{\star}$, MQ leg., SF det., CA coll.; Burcei, Rio Ollastu, 18.IV.2019, $10^{7}$, MQ leg., SF det., CA coll.

Distribution: widespread in the Palaearctic region and North Africa (Algeria, Morocco, and Tunisia) [49].

Range in Italy: this species is distributed throughout continental Italy and Sicily.

Andrena (Euandrena) granulosa Pérez, 1902

Andrena granulosa Pérez 1902. P.-v. Soc. linn. Bordeaux, 57: CLXXIX.

Examined specimens: Calich, Punta dell'Eru, 11.V.2019, 1 q, PN leg., MQ det., CA coll.

Distribution: widespread in Europe (except for the colder areas) and North Africa (Morocco) [47].

Range in Italy: this species is discontinuously present in the Italian peninsula.

Andrena (Melandrena) cineraria (Linnaeus, 1758)

Apis cineraria Linnaeus 1758. Syst. nat. (Ed. 10) 1: 575.

Examined specimens: Tissi, 15.V.1956, $10^{7}$, VN det. and coll.

Distribution: widespread in the Palaearctic region [49].

Range in Italy: this species is distributed throughout continental Italy.

Andrena (Micrandrena) tenuistriata Pérez, 1895

Andrena tenuistriata Pérez, 1895. Pérez 1895: 44

Examined specimens: Olmedo, Strada Statale 291, Janna de Mare, 10.III.2019, 1 \%, on Calendula sp., PN leg., SF det., CA coll.

Distribution: Southwestern Europe and North Africa (Morocco, Algeria, Tunisia, and Libia)

Range in Italy: this species is discontinuously present in the Italian peninsula and Sicily. Andrena (Micrandrena) rugulosa Stöckhert, 1935

Andrena rugulosa Stöckhert, 1935 Dt. ent. Z. 1935: 66

Examined specimens: Burcei, Rio Ollastu, 18.IV.2019, 1 \%, MQ leg., VN det., CA coll.

Distribution: Very rare species in Europe, with a distribution range from the northwestern part of the Alps to Crimea [47].

Range in Italy: so far known in Italy only in a locality in the extreme Italian border of the Trieste Karst [53].

Andrena (Notandrena) pallitarsis Pérez, 1903

Andrena pallitarsis Pérez 1903. P.-v. Soc. linn. Bordeaux, 58: LXXXIX. 
Examined specimens: Villanova Monteleone, Sa Serra, 26.VIII.2017, $1 \sigma^{\pi}$, on Foeniculum vulgare Mill. (Apiaceae), PN leg., VN det., RC coll.

Distribution: widespread in Europe (including Urals), and West Asia (Armenia, and Georgia) [49].

Range in Italy: this species is present in the regions of northern Italy.

Andrena (Suandrena) savignyi Spinola, 1838

Andrena savignyi Spinola 1838. Annls Soc. ent. Fr., 7: 512.

Examined specimens: Platamona, 23.IX.2017, 4 우, MQ leg. and det., CA coll.

Distribution: Southwestern Europe, North Africa (Algeria, Egypt, Lybia, and Morocco) and West Asia (Israel and the United Arab Emirates) [49].

Range in Italy: this species is known in the regions of Central and Southern Italy.

\section{Fam. HALICTIDAE}

Gen. Sphecodes Latreille, 1804

Sphecodes reticulatus Thomson, 1870

Sphecodes reticulatus Thomson, 1870. Opuscula entomologica. Bd. 2. Håkan Ohlson, Lund, 98

Examined specimens: Dorgali, Oddoene, 9.VI.2018, $1 \sigma^{7}$, PN leg. and det.

Distribution: this species occurs throughout the Palearctic region but is rare within much of its distribution area.

Range in Italy: this species is distributed throughout continental Italy and Sicily.

Fam. MEGACHILIDAE

Gen. Lithurgus Latreille, 1825

Lithurgus (Lithurgus) tibialis Morawitz, 1875

Lithurgus tibialis Morawitz 1875. Fedtschenko, Izv. Imp. Obsestva. Lûbit. Estestv. Antropol. Etnogr., 19: 103.

Examined specimens: Alghero, Mastr'Antoni, 5.VIII.2018 $1 \sigma^{7}$, on Chrozophora tinctoria (L.) A. Juss. (Euphorbiaceae); Uri, Cuga, 10.VII.2019, 1 ơ PN leg. and det., CA and US coll. Distribution: Southern Europe, Northern Africa, Eastern Mediterranean (Cyprus),

Central Asia (Turkmenistan), and Southern Asia (Iran, and Pakistan) [31].

Range in Italy: this species is present only in Sicily.

Gen. Chelostoma Latreille, 1809

Chelostoma (Chelostoma) emarginatum (Nylander, 1856)

Heriades emarginata Nylander 1856. Mem. Soc. des Sciences Nat. de Cherbourg, 4: 109.

Examined specimens: Villanova Monteleone, Sa Serra, 7.V.2017, 1 q, on Ranunculus sp. (Ranunculaceae), PN leg., VN det., RC coll.

Distribution: widespread in Europe and Southwestern Asia (Iran and Turkey) [54].

Range in Italy: this species is distributed throughout continental Italy and Sicily.

Gen. Dioxys Lepeletier and Serville, 1825

Dioxys cinctus (Jurine, 1807)

Trachusa cincta Jurine 1807. Nouv. method. class. Hymenopter., 1: 253.

Examined specimens: Ploaghe, 16.V.1956, 1 ㅇ, VN det. and coll.

Distribution: Central Europe and North Africa [28].

Range in Italy: this species is distributed throughout continental Italy and Sicily.

Gen. Coelioxys Latreille, 1809

Coelioxys (Allocoelioxys) caudatus Spinola, 1838

Coelioxys caudatus Spinola 1838. Ann. Soc. ent. France, 7: 535.

Examined specimens: Milis, Santu Simoni, 9.VII.1974, $10^{7}$, VN det. and coll.

Distribution: Southwestern Europe, North Africa (Algeria and Morocco), and Western Asia (Armenia, Azerbaijan, Georgia, Israel, and Turkey) [49]. 
Range in Italy: this species is discontinuously present in the Italian peninsula and in Sicily.

Coelioxys (Allocoelioxys) obtusus Pérez, 1884

Coelioxys obtusus Pérez 1884. Act. soc. Linn. Bordeaux, 37: 279.

Examined specimens: Rio Flumini Mannu, Assemini, 2.VII.1992, $4 \sigma^{7} \sigma^{7}$, on Ammi visnaga (L.) Lam. (Apiaceae), CM leg., VN det. and coll.

Distribution: Southwestern Europe, North Africa (Algeria, Egypt, and Morocco), and Western Asia (Armenia, Azerbaijan, Georgia, Iraq, and Turkey) [49].

Range in Italy: this species is discontinuously present in the Italian peninsula and in Sicily.

Gen. Megachile Latreille, 1802

Megachile (Pseudomegachile) ericetorum (Lepeletier, 1841)

Megachile ericetorum Lepeletier 1841. Hist. Nat. Insectes Hyménopt., 2: 341.

Examined specimens: Sassari, 18.VII.1997, $10^{7}$, AS leg., MQ det., US coll.; Uri, Cuga, 25.VI.2019, $10^{7}$, PN leg and det., US coll.

Distribution: widespread in Europe (except for the colder areas), Northern Africa, Eastern Mediterranean (Cyprus), Southern Asia (Iran), and Eastern Asia (China) [31].

Range in Italy: this species is distributed throughout continental Italy and Sicily.

Fam. APIDAE

Gen. Nomada Scopoli, 1770

Nomada melathoracica Imhoff, 1834

Nomada melathoracica Imhoff 1834. Isis 1834, p. 373.

Examined specimens: Porto Ferro, 28.IV.2018, 10 $0^{7}$, PN leg. and det., US coll.

Distribution: widespread in Europe (except for the colder areas) and Middle East (Turkey) [48].

Range in Italy: this species is known in the regions of Northern and Central Italy.

Nomada pulchra Arnold, 1888

Nomada pulchra Arnold, 1888. Horae Soc. ent. ross. 22, p. 202.

Examined specimens: Calich, Punta dell'Eru, 11.V.2019, $10^{\circ}$, PN leg., RC det., CA coll.

Distribution: widespread in Europe, Middle East (Turkey), and Asia (Kazakhstan and Eastern Siberia) [48].

New for Italy and Sardinia.

Gen. Eucera Scopoli, 1770

Eucera (Eucera) proxima Morawitz, 1875

Eucera proxima Morawitz 1875. Fedtschenk, Reise Turkestan, Apidae I., p.61.

Examined specimens: Uri, Rio Carrabusu, 19.IV.2018, 1 q, PN leg., MQ det., CA coll.

Distribution: widespread in Europe (except the colder areas), Eastern Mediterranean (Cyprus) Western Asia (Syria and Turkey), Central Asia (Turkmenistan, Uzbekistan, and Tajikistan), and Southern Asia (Iran) [31]. in Sicily.

Range in Italy: this species is discontinuously present in the Italian peninsula and

Gen. Tetralonia Spinola, 1838

Tetralonia (Tetralonia) malvae (Rossi, 1790)

Apis malvae Rossi 1790. Fauna Etrusca II., p. 107.

Examined specimens: Dorgali, Oddoene, 10.VI.2018, 1 \&, $1 \sigma^{7}$, on Althaea rosea L. (Malvaceae), PN leg. and det., US coll.

Distribution: widespread in Europe, Eastern Mediterranean (Cyprus), and Western Asia (Turkey) [31].

Range in Italy: this species is discontinuously present in the Italian peninsula and in Sicily. 
Shortly before submitting our paper, we became aware of the existence of a record for this species: Gonnosfanadiga, 39.49361, 8.66, (sex?), 6.VI.1943, D. Dale leg., B. Pittioni det., preserved at the Snow Entomological Museum, University of Kansas (Kansas, USA) [55].

Our specimens confirm the presence of the species on the island 78 years later.

\section{Discussion}

Currently, 316 species of bees are known in Sardinia [22]. Data on bees are lacking for most of the central and southern areas of the island, whereas much more data are available for the northwestern area of Sardinia. This was thanks to the work carried out by the Department of Agricultural Sciences of the University of Sassari, especially from 1997 to 2010, when a survey on wild pollinators was conducted, jointly with eight other research teams in Italy, using a unique scheme for monitoring the bee fauna [18]. The increased knowledge of this group of insects is of primary importance for knowing the local populations of pollinators of wild and cultivated plants $[18,56]$. In this context, studies have focused on the role of pollinators in certain agroecosystems or crops, such as the pollinators of white clover (Trifolium repens L.) in northern Sardinia [57], where the primary role of the wild bees belonging to Andrena, Megachile, and Osmia genera was evidenced. A study [58] on the pollinating insects of Hedysarum coronarium L. in northern Sardinia reported a total of 18 wild bee species, among which Eucera numida Lep. visited the crop most actively, followed by the endemic Bombus subspecies (B. ruderatus sardiniensis and $B$. terrestris sassaricus), Osmia bicornis L., and Megachile parietina Geoffroy. A survey of bee fauna in two different agroecosystems (semi-intensive vs. extensive) located in northern Sardinia (Nurra) [21] evidenced 28 species belonging to the Andrenidae, Halictidae, Megachilidae, and Apidae families in the semi-intensive agroecosystem compared to 31 species in the extensive agroecosystem, which showed the same families plus Colletidae. The results indicate that agriculture intensification did not lead to a significant decrease in species richness. However, the Sorensen's community index showed a medium similarity between the insect composition of the two landscapes. The effect of agricultural intensification was particularly evident on Collectidae, Andrenidae, and Halictidae species that usually use the soil as nesting sites. In fact, these families were more represented in the extensive site, probably thanks to the minimum tillage and the wider availability of uncultivated zones compared to the semi-intensive area. On the contrary, the semi-intensive landscape had a higher number of Megachilidae and Apidae species recorded, compared to the extensive one, probably because of the presence of forage legume crops.

\section{Conclusions}

Here, we report the following 11 genera of Hymenoptera Apoidea for Sardinia: Colletes (two species), Andrena (seven spp.), Sphecodes (one sp.), Lithurgus (one sp.), Chelostoma (one sp.), Dioxys (one sp.), Coelioxys (two spp.), Megachile (one sp.), Nomada (two spp.), Eucera (one sp.), and Tetralonia (one sp.). Precisely, the following 20 new species are reported as first records for the island of Sardinia: Colletes cunicularius, C. eous (Colletidae), Andrena humilis, A. granulosa, A. cineraria, A. tenuistriata, A. rugulosa, A. pallitarsis, A. savignyi (Andrenidae), Sphecodes reticulatus (Halictidae), Lithurgus tibialis, Chelostoma emarginatum, Dioxys cinctus, Coelioxys caudatus, C. obtusus, Megachile ericetorum (Megachilidae), Nomada melathoracica, N. pulchra, Eucera proxima, and Tetralonia malvae (Apidae). Moreover, N. pulchra is new not only for Sardinia but also for Italy.

Understanding the diversity of pollinators in an insular context and how it can be preserved is an important step for better understanding the biodiversity of this fauna at the global level. In fact, the latter certainly requires more efforts to collect observational and experimental data, to monitor the situation, and to conduct detailed surveys to determine pollinator diversity and the threats behind their decline. In particular, in the islands, the pollinator diversity is the result of a long and diffuse coevolution with floral diversity and nest conditions, which lead, thanks to isolation, to speciation processes with richness of endemism. 
Author Contributions: Conceptualization, I.F., S.B., M.Q., V.N. and R.C.; methodology, M.Q., I.F. and A.S.; software, I.F., A.S. and M.P.; validation, M.Q., S.B., V.N. and I.F.; formal analysis, V.N., S.B., R.C., S.F. and I.F.; investigation, V.N., S.B., M.Q., I.F., A.S., S.F., P.N. and M.P.; resources, M.Q., V.N., S.B., I.F., A.S. and M.P.; data curation, M.Q., S.B., V.N., R.C., S.F., A.S. and I.F.; writing-original draft preparation, I.F., S.B., M.Q., A.S. and M.P.; writing-review and editing, I.F., S.B., R.C., A.S. and M.P.; visualization, I.F., A.S. and M.P.; supervision, I.F., S.B. and M.Q.; project administration, I.F.; funding acquisition, I.F. All authors have read and agreed to the published version of the manuscript.

Funding: This research was funded by RESTART-UNINUORO Project "Azioni per la valorizzazione delle risorse agroforestali della Sardegna centrale/Actions for the valorisation of agroforestry resources in central Sardinia" Regione Autonoma della Sardegna, D.G.R. N. 29/1 del 7 June 2018-fondi FSC 2014-2020.

Institutional Review Board Statement: Not applicable.

Data Availability Statement: The data presented in this study are available on request from the corresponding author.

Conflicts of Interest: The authors declare no conflict of interest. The funders had no role in the design of the study; in the collection, analyses, or interpretation of data; in the writing of the manuscript, or in the decision to publish the results.

\section{References}

1. Myers, N.; Mittermeier, R.A.; Mittermeier, C.G.; da Fonseca, G.A.B.; Kent, J. Biodiversity hotspots for conservation priorities. Nature 2000, 403, 853-858. [CrossRef]

2. Michener, C.D. The Bees of the World, 2nd ed.; John Hopkins University Press: Baltimore, MD, USA, $2007 ;$ p. 953.

3. Nieto, A.; Roberts, S.P.M.; Kemp, J.; Rasmont, P.; Kuhlmann, M.; Criado, M.G.; Biesmeijer, J.C.; Bogusch, P.; Dathe, H.H.; la Rúa, P.D.; et al. European Red List of Bees; Publication Office of the European Union: Luxembourg, 2014; p. 86.

4. Orr, M.C.; Hughes, A.C.; Chesters, D.; Pickering, J.; Zhu, C.D.; Ascher, J.S. Global Patterns and Drivers of Bee Distribution. Curr. Biol. 2020, 31, 1-8.

5. Sánchez-Bayoa, K.; Wyckhuys, A.G. Worldwide decline of the entomofauna: A review of its drivers. Biol. Conserv. 2019, 232, 8-27. [CrossRef]

6. Wagner, D.L. Insect Declines in the Anthropocene. Annu. Rev. Entomol. 2020, 65, 457-480. [CrossRef]

7. Biesmeijer, J.B.; Roberts, S.P.M.; Reemer, M.; Ohlemüller, R.; Edwards, M.; Peeters, T.; Schaffers, A.P.; Potts, S.G.; Kleukers, R.; Thomas, C.D.; et al. Parallel Declines in Pollinators and Insect-Pollinated Plants in Britain and the Netherlands. Science 2006, 313, 351-354. [CrossRef]

8. Carvalheiro, L.G.; Kunin, W.E.; Keil, P.; Aguirre-Gutierrez, J.; Ellis, W.N.; Fox, R.; Groom, Q.; Hennekens, S.; Van Landuyt, W.; Maes, D.; et al. Species richness declines and biotic homogenisation haveslowed down for NW-European pollinators and plants. Ecol. Lett. 2013, 16, 870-878. [CrossRef] [PubMed]

9. IPBES. Assessment Report on Pollinators, Pollination and Food Production, 4th ed.; Intergovernmental Science-Policy Platform on Biodiversity and Ecosystem Services: Bonn, Germany, 2016.

10. La Greca, M. Il contributo degli Ortotteri e dei Mantodei alla conoscenza della biogeografia di Sardegna. Lav. Della Soc. Ital. Di Biogeogr. 1980, 8, 557-577. [CrossRef]

11. Casale, A.; Vigna Taglianti, A. Coleotteri Carabidi di Sardegna e delle piccole isole circumsarde, e loro significato biogeografico (Coleoptera, Carabidae). J. Integr. Biogeogr. Lav. Della Soc. Ital. Di Biogeogr. 1996, 18, 391-427. [CrossRef]

12. Alfken, J.D. Contributi alla conoscenza della fauna entomologica della Sardegna. Apidae. Mem. Della Soc. Entomol. Ital. 1938, 16, 97-114.

13. Guiglia, D. Contributi alla conoscenza della fauna imenotterologica della Sardegna, III. Imenotteri raccolti in Sardegna dal Prof. F.B. Boselli. Ann. Del Mus. Civ. Di Stor. Nat. Di Genova 1948, 63, 197-204.

14. Grandi, G. Campagna di ricerche dell'Istituto di Entomologia dell’Università di Bologna nella Sardegna settentrionale. Svolgimento e risultati della campagna. Ann. Dell Accad. Ital. di Sci. For. 1957, 6, 151-164.

15. Prota, R. Entomofauna delle aree montane. In Montagne Di Sardegna; Camarda, I., Ed.; Delfino Editore: Sassari, Italy, 1993; pp. 104-125.

16. Nobile, V. Api (Insecta, Hymenoptera) nuove o poco note di Sicilia e Sardegna. Boll. Dell Accad. Gioenia Di Sci. Nat. 1995, 28, 147-159.

17. Nobile, V.; Tomarchio, S. Apoidei nuovi o poco noti di alcune regioni d'Italia. I. Boll. Dell Accad. Gioenia Di Sci. Nat. 2000, 33, 43-54.

18. Quaranta, M.; Ambroselli, S.; Barro, P.; Bella, S.; Carini, A.; Celli, G.; Cogoi, P.; Comba, L.; Comoli, R.; Felicioli, A.; et al. Wild bees in agroecosystems and semi-natural landscapes. 1997-2000 collection period in Italy. Bull. Insectology 2004, 57, 11-61.

19. Nobile, V.; Meloni, C.; Tomarchio, S. Andrena nuove per la Sicilia e la Sardegna (Hymenoptera Andrenidae). Boll. Della Soc. Entomol. Ital. 2005, 137, 223-228. 
20. Satta, A.; Floris, I.; Ruiu, L. Indagini sugli insetti impollinatori di differenti ambienti agricoli della Sardegna settentrionale. In $I l$ Ruolo Della Ricerca in Apicoltura, Proceedings of the Final Congress AMA Project, Bologna, Italy, 14-16 March 2002; Sabatini, A.G., Bolchi Serini, G., Frilli, F., Porrini, C., Eds.; Litosei: Bologna, Italy, 2002; pp. 385-390.

21. Floris, I.; Satta, A.; Lentini, A. Monitoring of insect pollinators in two different agricultural landscapes (Sardinia, Italy). Insect Soc. Life 2000, 3, 115-118.

22. Comba, M. Hymenoptera: Apoidea: Anthophila of Italy. Available online: http://digilander.libero.it/mario.comba (accessed on 16 November 2020).

23. Nobile, V.; Turrisi, G.F. New or little known Halictidae from Italy (Hymenoptera, Apoidea). Boll. Della Soc. Entomol. Ital. 2015, 147, 39-42. [CrossRef]

24. Nobile, V.; Turrisi, G.F. New or little known Nomada Scopoli from Italy (Hymenoptera, Apoidea, Apidae). Boll. Della Soc. Entomol. Ital. 2016, 148, 51-55. [CrossRef]

25. Mazzeo, G.; Bella, S.; Seminara, A.R.; Longo, S. Bumblebees in natural and agroecosystems at different altitudes from Mount Etna, Sicily (Hymenoptera Apidae Bombinae): Long-term faunistic and ecological observations. Redia 2015, 98, 123-131.

26. Mazzeo, G.; Longo, S.; Seminara, A.R.; Bella, S. Faunistic and ecological studies on Apidae (Hymenoptera Apoidea) in natural and cultivated ecosystems in Sicily. Redia 2019, 102, 153-162. [CrossRef]

27. Bella, S.; Catania, R.; Nobile, V.; Mazzeo, G. New or little-known bees from Sicily (Hymenoptera: Apoidea). Fragm. Entomol. 2020, 52, 113-117. [CrossRef]

28. Turrisi, G.F.; Altadonna, G.; Lo Cascio, P.; Nobile, V.; Selis, M. Contribution to the knowledge of Hymenoptera from the Aeolian Archipelago (Sicily), emphasizing Aculeata. Biodivers. J. 2020, 11, 717-750. [CrossRef]

29. Balzan, M.V.; Rasmont, P.; Kuhlmann, M.; Dathe, H.H.; Pauly, A.; Patiny, S.; Terzo, M.; Michez, D. The bees (Hymenoptera: Apoidea) of the Maltese Islands. Zootaxa 2016, 4162, 225-244. [CrossRef]

30. Balzan, M.; Genoud, D.; Rasmont, P.; Schwarz, M.; Michez, D. New records of bees (Hymenoptera: Apoidea) from the Maltese Islands. J. Melittology 2017, 72, 1-9. [CrossRef]

31. Varnava, A.I.; Roberts, S.P.M.; Michez, D.; Ascher, J.S.; Petanidou, T.; Dimitriou, S.; Devalez, J.; Pittara, M.; Stavrinides, M.C. The wild bees (Hymenoptera, Apoidea) of the island of Cyprus. ZooKeys 2020, 924, 1-114. [CrossRef]

32. Baldock, D. A provisional list of the wasps and bees of Mallorca, Balearic Islands, Spain (Hymenoptera aculeata: Chrysidoidea, Scolioidea, Vespoidea, Apoidea). Entomofauna 2014, 35, 333-404.

33. Müller, A. New European bee species of the tribe Osmiini (Hymenoptera: Apoidea: Megachilidae). Zootaxa 2012, 3355, 29-50. [CrossRef]

34. Müller, A. Palaearctic Osmia bees of the subgenus Hoplosmia (Megachilidae, Osmiini): Biology, taxonomy and key to species. Zootaxa 2018, 4415, 297-329. [CrossRef]

35. Quaranta, M.; Cornalba, M.; Biella, P.; Comba, M.; Battistoni, A.; Rondinini, C.; Teofili, C. Lista Rossa IUCN Delle Api Italiane Minacciate (IUCN Red List of Italian Threatened Bees); Comitato Italiano IUCN e Ministero dell'Ambiente e della Tutela del Territorio e del Mare: Roma, Italy, 2018; p. 67.

36. Camarda, I.; Laureti, L.; Angelini, P.; Capogrossi, R.; Carta, L.; Brunu, A. Il Sistema Carta della Natura della Sardegna. IspraSer. Rapp. 2015, 222, 2015.

37. Mapping Habitats to Describe Ecosystems. Available online: https://www.eea.europa.eu/highlights/mapping-habitats-todescribe-ecosystems (accessed on 26 May 2021).

38. Friese, H.; Apidae, I. Megachilinae. Das Tierreich 28Berl; MBLWHOI Library: Woods Hole, MA, USA, $1911 ;$ p. 440.

39. Ebmer, A.W. Die Bienen des Genus Halictus Latr. s.l. im Großraum von Linz. (Hymenoptera, Apidae). Teil I. Nat. Jahrb. Stadt Linz 1969, 15, 133-184.

40. Ebmer, A.W. Die Bienen des Genus Halictus Latr. s.l. im Großraum von Linz. Teil II. (Hymenoptera, Apidae). Nat. Jahrb. Stadt Linz 1970, 16, 19-82.

41. Ebmer, A.W. Die Bienen des Genus Halictus Latr. s.l. im Großraum von Linz. Teil III. (Hymenoptera, Apidae). Nat. Jahrb. Stadt Linz 1971, 17, 63-156.

42. Ebmer, A.W. Die Bienen des Genus Halictus Latr. s.l. im Großraum von Linz. (Hymenoptera, Apidae). Nat. Jahrb. Stadt Linz 1974, 19, 123-158.

43. Dylewska, M. Die Gattung “Andrena” Fabricius (Andrenidae, Apoidea) in Nord-und Mitteleuropa. Acta Zool. Crac. 1987, 30, 359-708.

44. Warncke, K. Die westpaläarktischen Arten der Bienengattung Coelioxys Latr. (Hymenoptera, Apidae, Megachilinae). Ber. Nat. Gesellsch. Augsbg. 1992, 53, 31-77.

45. Schmid-Egger, C.; Scheuchl, E. Illustrierte Bestimmungstabellen der Wildbienen Deutschlands und Österreichs Unter Berücksichtigung der Arten der Schweiz. Band III; Andrenidae: Eigenverlag, Velden, 1997; 180 Seiten.

46. Scheuchl, E. Illustrierte Bestimmungstabellen der Wildbienen Deutschlands und Österreichs. Band I: Anthophoridae. 2. Erweiterte Auflage; Eigenverlag: Berlin, Germany, 2000; p. 158.

47. Scheuchl, E. Illustrierte Bestimmungstabellen der Wildbienen Deutschlands und Österreichs Für Osmia s.1. Unter Berücksichtigung der Arten der Schweiz, Norditaliens, Ungarns, Sloweniens und der Slowakei. Band II, Schlïssel der Arten der Familien Megachilidae und Melittidae, 2nd ed.; Apollo Books: Tsim Sha Tsui, Japan, 2006; p. 192. 
48. Smit, J. Identification Key to the European Species of the bee genus Nomada Scopoli 1770 (Hymenoptera: Apidae), Including 23 New Species; Entomofauna, Monographie; Museum Witt: Munich, Germany, 2018; Volume 3, p. 250.

49. Kuhlmann, M.; Ascher, J.S.; Dathe, H.H.; Ebmer, A.W.; Hartmann, P.; Michez, D.; Müller, A.; Patiny, S.; Pauly, A.; Praz, C.; et al. Checklist of the Western Palaearctic Bees (Hymenoptera: Apoidea: Anthophila). 2018. Available online: http: // westpalbees.myspecies.info (accessed on 16 November 2020).

50. Rasmont, P.; Haubruge, E. Atlas Hymenoptera. Université de Mons, Gembloux Agro Bio Tech, Mons, Gembloux, Belgium 2015. Available online: www.atlashymenoptera.net (accessed on 12 September 2020).

51. Polaszek, A.; Mitroiu, M.-D. Fauna Europaea: Apidae. In 2013 Fauna Europaea: Hymenoptera-Apocryta. Fauna Europaea Version 2.6. Available online: www.faunaeu.org (accessed on 12 September 2020).

52. Ascher, J.S.; Pickering, J. Discover Life Bee Species Guide and World Checklist (Hymenoptera: Apoidea: Anthophila). 2020. Available online: http:/ / www.discoverlife.org/mp/20q?guide=Apoidea_species (accessed on 27 April 2021).

53. Gusenleitner, F. Faunistische und morphologische Angaben zu Bemerkens-Werten Andrena-Arten aus Österreich. (Insecta: Hymenoptera: Apoidea: Andrenidae). Linz. Biol. Beiträge 1984, 16, 211-276.

54. Ungricht, S.; Müller, A.; Dorn, S. A taxonomic catalogue of the Palaearctic bees of the tribe Osmiini (Hymenoptera: Apoidea: Megachilidae). Zootaxa 2008, 1865, 1-253. [CrossRef]

55. Bentley, A.; Thomas, J. Snow Entomological Museum Collection. Version 26.49. University of Kansas Biodiversity Institute 2021, Occurrence Dataset. Available online: https://www.gbif.org/occurrence/911630205. (accessed on 27 April 2021).

56. Cocuzza, G.E.M.; Mazzeo, G.; Russo, A.; Lo Giudice, V.; Bella, S. Pomegranate arthropod pests and their management in the Mediterranean area. Phytoparasitica 2016, 44, 393-409. [CrossRef]

57. Ortu, S.; Floris, I.; Pampaloni, S. Osservazioni su insetti impollinatori di trifoglio bianco (Trifolium repens L.) in Sardegna. Apic. Mod. 1991, 82, 103-111.

58. Satta, A.; Floris, I.; Acciaro, M. Observations on the insects pollinating Hedysarum coronarium L., in Sardinia (Italy). Insect Soc. Life 2000, 3, 161-166. 